\title{
Deuterium oxide dilution can be used to determine the net energy content of feeds for dairy cattle and goats
}

\author{
Dan L. Brown \\ Department of Animal Science, Cornell University, New York, USA; dlb20@cornell.edu \\ Received 3 February 2013; revised 10 March 2013; accepted 7 April 2013 \\ Copyright (C) 2013 Dan L. Brown. This is an open access article distributed under the Creative Commons Attribution License, which \\ permits unrestricted use, distribution, and reproduction in any medium, provided the original work is properly cited.
}

\begin{abstract}
This article explores a technique for measuring the energy $\left(N E_{L}\right)$ value of feeds without respiration calorimetry or slaughter. The objectives were to compare results obtained from goats with those from cows, and to describe factors which limited the precision of these $\mathrm{NE}_{\mathrm{L}}$ estimates. One lactating Alpine doe and one lactateing Holstein cow were assigned to each of six different sequences of three 56-d feeding treatments consisting of low, medium, and high doses of the basal diet, rice bran, or hominy feed. This resulted in $\mathbf{3 0}$ observations of the basal diet and 12 of each byproduct feed for each species and utilized a total of 18 cows and 18 does. The $\mathrm{NE}_{\mathrm{L}}$ values of the basal diet, rice bran, and hominy feed were calculated as the sum of milk energy, change in body energy, and estimated fasting heat production per kilogram of feed dry matter. Milk energy was determined by bomb calorimetry and body energy from live body weight and deuterium oxide space. The $\mathrm{NE}_{\mathrm{L}}$ $(\mathrm{MJ} / \mathrm{kg})$ determined in this manner were basal diet, 5.73 and 5.98; rice bran, 7.11 and 7.07; and hominy feed, 6.99 and 8.20 for cows and goats, respectively.
\end{abstract}

Keywords: Net Energy; Deuterium; Dairy; Goats; Cattle

\section{INTRODUCTION}

Accurate net energy values for feed ingredients are a critical part of the information that dairy producers need to feed their cows for optimal production efficiency. The industry has available a much broader selection of byproduct feeds than it once had, but estimation of the energy concentration in those special feeds is a problem.
Equations that predict net energy for lactation $\left(\mathrm{NE}_{\mathrm{L}}\right)$ from fiber, protein, near infrared reflectance, and other rapid feed analyses were based on a limited number of large animal calorimetric determinations. These $\mathrm{NE}_{\mathrm{L}}$ determinations have been performed for alfalfa, grains, and other traditional dairy feeds, but not for the diverse, currently available byproducts. In most cases, a general formula is used to create tabular feed $\mathrm{NE}_{\mathrm{L}}$ values from total digestible nutrients (TDN) or digestible energy values. Often the TDN or digestible energy values themselves were predicted from fiber content rather than directly measured. When the relationship between fiber content and $\mathrm{NE}_{\mathrm{L}}$ for a new feed is different from those described by $\mathrm{NE}_{\mathrm{L}}$ prediction equations, errors may occur in the formulation of diets that include the new feed. Errors in estimation of feed energy and prediction of animal performance are costly to dairy producers because their profits depend on minimizing feed costs and maintenance of proper body condition for efficient rebreeding and preparation for the next lactation.

The three main goals for these trials were 1) to explore a technique for measuring the $\mathrm{NE}_{\mathrm{L}}$ value of feeds without respiration calorimetry or slaughter, 2) to compare results obtained from lactating dairy goats with those from lactating dairy cows, and 3) to describe factors that limited the precision of these $\mathrm{NE}_{\mathrm{L}}$ estimates and thereby enable other workers to improve this technique.

\section{MATERIALS AND METHODS}

The following procedures were reviewed and approved by the University of California, Davis Animal Use and Care Committee as Approved Protocol \#3429. This work was performed at the University of California when the author was a member of that faculty.

\subsection{Body Composition and Energy}

The body composition and energy content of the cows 
and does were determined from live body weight and deuterium oxide $\left(\mathrm{D}_{2} \mathrm{O}\right)$ dilution space before and after each 56-d feeding period according to the methods of Brown et al. [1] for cows and Brown and Taylor [2] for goats. Animals of the same sizes and types, diets of the same physical form and approximately same chemical composition, and the same animal care facilities were used in this trial as were used to establish these methods. Intrajugular injections of about 75 and $7.5 \mathrm{~g}$ of $\mathrm{D}_{2} \mathrm{O}$ were administered to cows and goats, respectively. The syringes used to administer the doses were weighed to the nearest $0.01 \mathrm{~g}$ before and after injections. The concentrations of $\mathrm{D}_{2} \mathrm{O}$ in milk samples from the following eight milkings were determined by an automated modification of the Byers infrared absorption assay [3]. Cow body fat, protein, and energy and goat body fat and protein were calculated as previously described $[1,2]$ with equations that yield body composition estimates unbiased by water turnover rates. Goat body energy was calculated as the sum of [body protein $(\mathrm{kg}) \times 24.794 \mathrm{MJ} / \mathrm{kg}$ ] + [body fat $(\mathrm{kg}) \times 38.614 \mathrm{MJ} / \mathrm{kg}]$.

\subsection{Estimated Fasting Heat Production}

The average body weight for any given test period was used to predict fasting heat production (HP) by the following equations:

Cow: HP $(\mathrm{kJ} / \mathrm{d})=260.96$ (body weight $)^{0.775}$

This equation is from Thonney et al. [4] based on reevaluation of data reported by Flatt and Coppock [5] and Goat: $\mathrm{HP}(\mathrm{kJ} / \mathrm{d})=428.86(\text { body weight })^{0.66}[6]$.

These equations were based on measurements of heat production from published studies of animals most similar to those used in this study.

\subsection{Feed and Milk Analyses}

Milk samples proportional to production ( $1 \%$ of total) were taken at each milking and composited by week. Milk energy was determined by bomb calorimetry (A. Gallenkamp \& Co., Ltd., London, England) of freezedried samples. Daily subsamples of feed offered and refused were taken and composited by period. Feeding cows required more than one batch of feed per period from the feed mill. Therefore, cattle feed samples were composited for analysis by batch, and period averages of appropriate batches were used to characterize the feeds for calculation of $\mathrm{NE}_{\mathrm{L}}$. All feeds were analyzed for ether extract (crude fat), crude protein, dry matter, ash, $\mathrm{Ca}$, and $\mathrm{P}$ by standard AOAC [7] procedures. The neutral detergent fiber, acid detergent fiber, and acid detergent insoluble $\mathrm{N}$ were determined by the methods of Goering and Van Soest [8]. The nutrient compositions of the three feeds for cows and goats are shown in Table 1. Each observation was the average of a pair of duplicate composite samples from each batch of diet or byproduct.

\subsection{Treatments and Animal Care}

Beginning 5 wk after freshening, all 36 subjects (18 Holstein cows and 18 French Alpine does) were offered the basal diet (Table 1) for ad libitum intake in a preliminary 14-d period. For each of the three feeds tested, one lactating Alpine doe and one lactating Holstein cow were assigned to each of six different sequences of three 56-d feeding treatments consisting of low, medium, and high doses of the basal diet; a medium and high dose of rice bran; or a medium and high dose of hominy feed. Table 2 shows feeding treatment sequences and exact

Table 1. Feed nutrient analyses for basal diet, rice bran and hominy feed consumed by cows and goats.

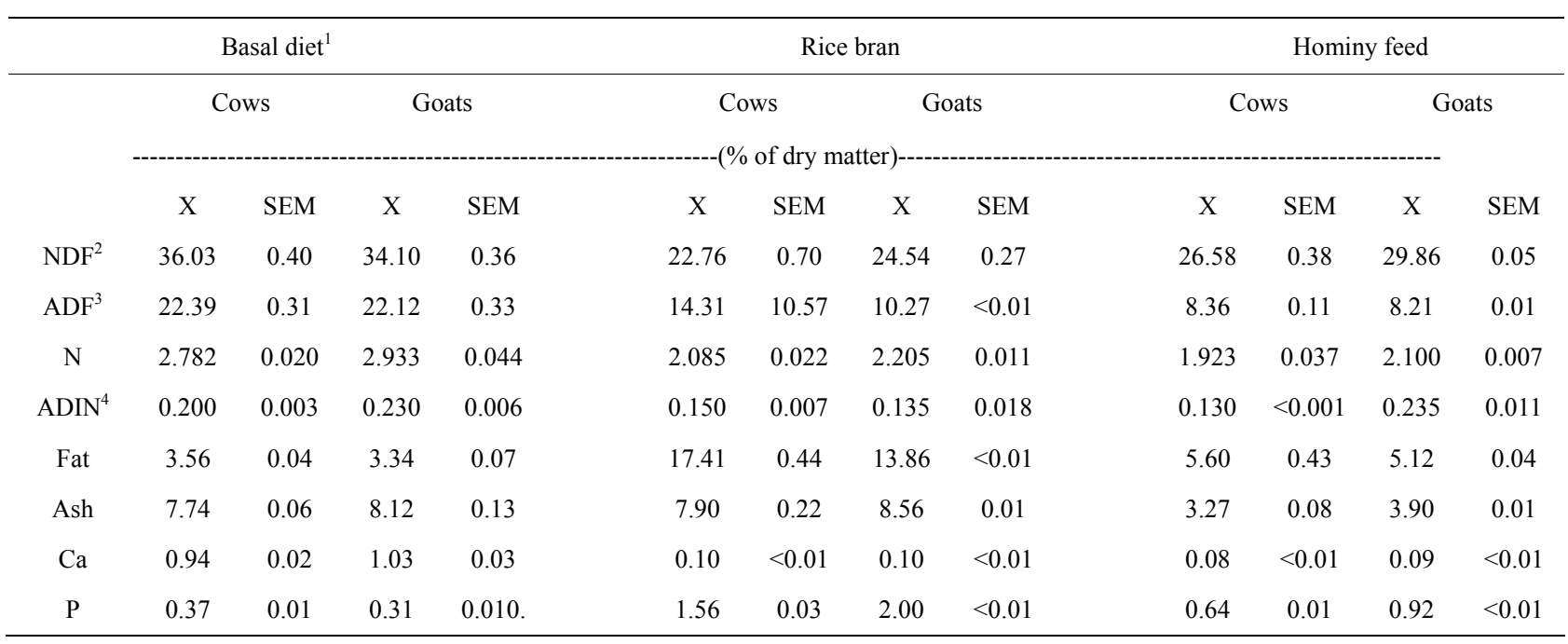

${ }^{1}$ Basal diet ingredients: $60 \%$ chopped alfalfa hay, $31 \%$ cracked corn grain, $4 \%$ cane molasses, $3 \%$ cottonseed meal, $1 \%$ animal fat, $0.5 \%$ dicalcium phosphate, and $0.5 \%$ trace mineralized salt. The trace mineralized salt contained the following: $96 \% \mathrm{NaCl}, 0.3 \% \mathrm{Zn}, 0.2 \% \mathrm{Mn}, 0.2 \% \mathrm{Fe}, 0.04 \% \mathrm{Cu}, 0.002 \% \mathrm{I}$. All values are guaranteed minimum analyses; ${ }^{2} \mathrm{NDF}=$ neutral detergent fiber; ${ }^{3} \mathrm{ADF}=$ acid detergent fiber; ${ }^{4} \mathrm{ADIN}=$ acid detergent insoluble nitrogen. 
Table 2. Feeding treatment sequences ${ }^{1}$.

\begin{tabular}{|c|c|c|c|}
\hline \multicolumn{4}{|c|}{ Period } \\
\hline $\mathrm{n}$ & 1 & 2 & 3 \\
\hline 1 & B & $\mathrm{B}+$ & $\mathrm{B}++$ \\
\hline 1 & B+ & B & $\mathrm{B}++$ \\
\hline 1 & $\mathrm{~B}++$ & $\mathrm{B}+$ & B \\
\hline 1 & B & $\mathrm{B}++$ & $\mathrm{B}^{+}$ \\
\hline 1 & $\mathrm{~B}+$ & $\mathrm{B}++$ & B \\
\hline 1 & $\mathrm{~B}++$ & B & $\mathrm{B}+$ \\
\hline 1 & B & $\mathrm{R}+$ & $\mathrm{R}++$ \\
\hline 1 & $\mathrm{R}+$ & B & $\mathrm{R}++$ \\
\hline 1 & $\mathrm{R}++$ & $\mathrm{R}+$ & B \\
\hline 1 & B & $\mathrm{R}++$ & $\mathrm{R}+$ \\
\hline 1 & $\mathrm{R}+$ & $\mathrm{R}++$ & B \\
\hline 1 & $\mathrm{R}++$ & B & $\mathrm{R}+$ \\
\hline 1 & B & $\mathrm{H}^{+}$ & $\mathrm{H}++$ \\
\hline 1 & $\mathrm{H}^{+}$ & B & $\mathrm{H}++$ \\
\hline 1 & $\mathrm{H}++$ & $\mathrm{H}^{+}$ & B \\
\hline 1 & B & $\mathrm{H}++$ & $\mathrm{H}+$ \\
\hline 1 & $\mathrm{H}^{+}$ & $\mathrm{H}++$ & B \\
\hline 1 & $\mathrm{H}++$ & B & $\mathrm{H}+$ \\
\hline
\end{tabular}

${ }^{1} \mathrm{~B}=22 \mathrm{~kg}$ (cattle) or $2.6 \mathrm{~kg}$ (goats) of basal diet; $\mathrm{B}+, \mathrm{R}+$, or $\mathrm{H}+=22 \mathrm{~kg}$ of basal plus $2 \mathrm{~kg}$ of basal, rice bran or hominy (cattle) or $2.6 \mathrm{~kg}$ of basal plus. $2 \mathrm{~kg}$ of basal, rice bran or hominy (goats); $\mathrm{B}++, \mathrm{R}++$, or $\mathrm{H}++=22 \mathrm{~kg}$ of basal plus $4 \mathrm{~kg}$ of basal, rice bran, or hominy (cattle) or $2.6 \mathrm{~kg}$ of basal plus. $4 \mathrm{~kg}$ of basal, rice bran, or hominy (goats), respectively.

doses. Assignments to sequences were balanced to cancel out period effects and to reduce bias caused by stage of lactation or by possible fluctuations in alfalfa quality over time. For each species, treatment assignments resulted in 30 observations of the basal diet: 18 at the low, 6 at the intermediate, and 6 at the highest dose. For each species, there were 12 observations for each byproduct tested, 6 at each dose in addition to the basal rations.

Cows were housed in individual paddocks, which provided separate areas for eating, rest, exercise, and defecation. Cows were milked twice daily beginning at about 0700 and $1800 \mathrm{~h}$. The 18 goats were housed together outdoors in a large exercise yard, except when they were confined to individual feeding stations (elevated dairy calf pens modified to prevent access to the adjacent goat's feed for $2 \mathrm{~h}$ after the morning feedings $(900 \mathrm{~h})$ and for $10 \mathrm{~h}$ between evening feedings $(2100 \mathrm{~h})$ and morning milkings. Cows and goats were provided water free choice at all times.

Increments of byproduct feed were mixed thoroughly by hand into the basal portions of each offering. Because dry matter offered was set as less than the estimated maximum voluntary intake, refusal of feed was infrequent. When refusal occurred, chemical analysis of orts showed that selection of diet components was not significant in either species.

\subsection{Calculations and Statistical Analysis}

The net energy used by each individual for each feeding period was calculated as the sum of 1) energy in milk secreted during the feeding period, 2) the change in estimated body energy that feeding period, and 3) the HP estimated from the average body weight during the feeding period.

The net energy content of the basal diet for each individual was calculated as the net energy used divided by the dry matter consumed. The mean of 30 basal diet net energy determinations for each species was used to calculate the net energy of the byproducts by difference. To determine the net energy of rice bran and hominy feed, the net energy attributable to the basal diet was subtracted from the total net energy used, and the remainder was divided by the amount of byproduct dry matter consumed. These net energy values are found in Table 3. Student's $t$ test was used to contrast means for goats and cows [9]. Null hypotheses of similar species means were accepted at $\mathrm{P}>0.05$ for the basal diet and both commodities.

\section{RESULTS AND DISCUSSION}

The net energy means for the basal diet were similar among cows $(5.73 \mathrm{MJ} / \mathrm{kg})$, does $(5.98 \mathrm{MJ} / \mathrm{kg})$, and a proportional combination of NRC [10] estimates for ingredients $(6.11 \mathrm{MJ} / \mathrm{kg}$ ) (Table 3). The measured values for the rice bran were only about $6 \%$ greater than the $\mathrm{NRC}$ tabular value $(7.11 \mathrm{MJ} / \mathrm{kg}$ for cows and $7.07 \mathrm{MJ} / \mathrm{kg}$ for does vs. $6.69 \mathrm{MJ} / \mathrm{kg}$ from $\mathrm{NRC}$ ). Although all rice bran came from the same supplier at the same time, the test rice bran fed to cows was richer in fat than the NRC [10] value (17.4 vs. $15.1 \%)$, and the rice bran fed to the goats contained a little less fat $(13.9 \%)$. This small difference in fat content may be contributed to the lower $\mathrm{NE}_{\mathrm{L}}$ estimated for goats. The $\mathrm{NE}_{\mathrm{L}}$ for hominy feed $(8.20$ $\mathrm{MJ} / \mathrm{kg}$ ) for goats compared well with the NRC value $(8.41 \mathrm{MJ} / \mathrm{kg})$, but the $\mathrm{NE}_{\mathrm{L}}$ concentration for hominy feed $(6.99 \mathrm{MJ} / \mathrm{kg}$ ) measured in cows was lower than the NRC value or that measured in goats, but that difference was not statistically significant.

Table 4 contains data showing that dry matter intake and body weight were similar for each period. As expected, milk energy production decreased with time.

\subsection{Value of $\mathrm{D}_{2} \mathrm{O}$ Dilution for Predicting Body Energy}

As reported previously $[1,2], \mathrm{D}_{2} \mathrm{O}$ dilution space is an 
Table 3. Mean net energy $\left(\mathrm{NE}_{\mathrm{L}}\right)$ values of basal diet, rice bran and hominy feed.

\begin{tabular}{ccccccc}
\hline & \multicolumn{2}{c}{ Cow } & Goats & & NRC $^{1}$ \\
\hline Feed & $\mathrm{n}$ & $\mathrm{X}$ & $\mathrm{SEM}$ & $\mathrm{X}$ & SEM & \\
Basal & 30 & 5.73 & 0.17 & 5.98 & 0.25 & 6.11 \\
Rice bran & 12 & 7.11 & 1.67 & 7.07 & 5.86 & 6.69 \\
Hominy feed & 12 & 6.99 & 1.17 & 8.20 & 1.80 & 8.41 \\
\hline
\end{tabular}

${ }^{1} \mathrm{NRC}[10]$ mean $\mathrm{NE}_{\mathrm{L}}$ values for cows did not differ from those for goats for any of the feeds $(\mathrm{P}>0.05)$.

Table 4. Period means and SEM for 56-d dry matter intake, milk energy production, average body weight, and change in body energy.

\begin{tabular}{|c|c|c|c|c|c|c|}
\hline & \multicolumn{6}{|c|}{ Period } \\
\hline & \multicolumn{2}{|c|}{1} & \multicolumn{2}{|c|}{2} & \multicolumn{2}{|c|}{3} \\
\hline & $\mathrm{X}$ & SEM & $\mathrm{X}$ & SEM & $\mathrm{X}$ & SEM \\
\hline \multicolumn{7}{|l|}{ Goats } \\
\hline Dry matter intake, $\mathrm{kg}$ & 139 & 2 & 140 & 2 & 139 & 2 \\
\hline Milk energy, MJ & 569 & 13 & 507 & 13 & 431 & 17 \\
\hline Body weight, $\mathrm{kg}$ & 52.5 & 1.2 & 54.6 & 1.4 & 55.4 & 1.6 \\
\hline Change in body energy, MJ & -7.5 & 27.6 & 116.6 & 26.5 & -78.1 & 39.9 \\
\hline \multicolumn{7}{|l|}{ Cows } \\
\hline Dry Matter, kg & 1106 & 26 & 1136 & 21 & 1112 & 22 \\
\hline Milk energy, MJ & 5103 & 126 & 4140 & 88 & 3592 & 163 \\
\hline Body weight, $\mathrm{kg}$ & 590 & 10 & 581 & 10 & 596 & 10 \\
\hline Change in body energy, MJ & -487.6 & 125.7 & 132.6 & 78.8 & 451.1 & 238.8 \\
\hline
\end{tabular}

important part (with body weight) of statistically significant, logistically practical models for prediction of body composition and energy. In the present study, body weight alone could not have predicted changes in body water and energy. For example, goat number 2006 (66.5 $\mathrm{kg}$ initial body weight) gained $10 \mathrm{~kg}$ of body weight and $201 \mathrm{MJ}$ of body energy during the period 1, gained 3.5 $\mathrm{kg}$ and $205 \mathrm{MJ}$ in period 2, and lost $385 \mathrm{MJ}$ during period 3 but gained $1.5 \mathrm{~kg}$. Cow number 1037 (598 kg initial body weight) lost $21 \mathrm{~kg}$ and $992 \mathrm{MJ}$ during period 1, lost $17 \mathrm{~kg}$ and gained $79 \mathrm{MJ}$ during period 2, and gained $40 \mathrm{~kg}$ and $1013 \mathrm{MJ}$ during period 3. Although that cow gained energy as [10] allowances predict (25.1 MJ of $\mathrm{ME}_{\mathrm{L}} / \mathrm{kg}$ of body weight gain) for period 3, she lost 47.28 $\mathrm{MJ} / \mathrm{kg}$ body weight in period 1 and gained 4.69 $\mathrm{MJ}$ for each $\mathrm{kg}$ lost in period 2. These findings suggest that the composition of lost tissue can vary substantially and differ from assumptions based on means of previous observations (e.g. $21.43 \mathrm{MJ}$ of $\mathrm{NE}_{\mathrm{L}}$ that are credited to each kilogram of live body weight loss by the NRC [10]).
Although most mean net energy concentrations were within the expected range, variation associated with some of these estimates was quite large (Table 3). Possible sources of variation include variation in test materials, experimental error that was due to scale and measurement problems, sample size (number of animals), and systematic variation introduced by the technique itself. The following discussion addresses the contribution of each factor to the variability within each $\mathrm{NE}_{\mathrm{L}}$ estimate and on suggestions to reduce the influence of each factor. The purpose of the following discussion is to help the reader to design methods of $\mathrm{NE}_{\mathrm{L}}$ measurements that are superior to those used in this study.

\subsection{Variation in Test Materials}

Although efforts were made to ensure that the basal diet remained absolutely uniform throughout these trials and the long feeding period needed to collect these data.

Unanticipated fluctuations in forage quality led to a $10 \% \mathrm{CV}$ in neutral detergent fiber among the 55 batches 
(totaling more than 40 metric tons) of basal diet mixed during this experiment. Because of reductions in bias from the arrangement of treatments, forage quality shifts probably did not affect the estimates of mean $\mathrm{NE}_{\mathrm{L}}$ values, but such shifts may have been a source of variability.

Much of the variation in test materials as a source of error could be removed by 1) mixing all diets in advance; 2) using one cutting of hay from one highly uniform field as the sole forage source; 3 ) thorough sampling, analysis, and screening of each batch as it came from the mill; and 4) conducting the trials over a short period (and simultaneously, if possible) to make those improvements more feasible.

\subsection{Scale and Measurement}

Measurement Devices. The feeds for both cows and goats were weighed to the nearest $0.05 \mathrm{~kg}$ at each feeding on the same type of milk scale. Because the same device was used to measure $24.0,26.0$, and $28.0 \mathrm{~kg}$ for the cows and $2.6,2.8$, and $3.0 \mathrm{~kg}$ for the goats, the potential influence for error inherent to the instrument was greater for the goats than for the cows. This factor may have introduced variation (but not bias) to estimates of dry matter intake.

Feeding Stations. The feeding apparatus used for the cattle resulted in quantitative recovery of orts, without exception. In contrast, differences in feeding station design and species behavior caused a very small, but variable, quantity of goat feed to be spilled. This spillage was reduced but not eliminated by designing feeding stations that forced goats to rotate their heads $90^{\circ}$ when withdrawing their heads from the feed bin. This rotation usually caused the goat to drop excess food back into the bin rather than to throw it around her pen. Further modifications would have been needed to capture even the small amount of feed lost in these trials.

Housing. Variation in the amount of exercise taken by goats in the outside pens was apparent but not measured. Some goats were quite active between feedings including playing, running, jumping, climbing, and fighting. Other does only rested between feedings. More confinement of goats would have reduced this source of variation in energy expenditure, but only at the loss of the freedom of movement and social interaction required for the humane care of this species. Activity of cows was neither extensive nor apparently variable but could be measured and considered for maximum precision in the future.

Scale of Feed Increment. Each increment of test feed (in this case, rice bran and hominy feed) was less than $10 \%$ of the total feed intake. This procedure had the advantage of causing only minimal changes in the overall nutrient and palatability characteristics of the diet. Unfortunately, it also increased the influence of the residual experimental error and error in estimates of basal diet energy concentrations on the estimate of byproduct $\mathrm{NE}_{\mathrm{L}}$ concentration. Both sources of error have greater influence when divided by a relatively small byproduct dry matter intake than they would if the test feed made up most of the diet. If a basal diet can be designed that meets non-energy nutrient requirements in any combination with a test feed, then we recommend that the test feed make up a greater proportion of the total feed than that used in our trials.

\subsection{Sample Size}

Confidence intervals on the basal diet estimates were narrower than byproduct estimates, partially because the basal diet estimate was based on 30 observations and the byproduct diet estimates were based on 12 observations each. Even if all other sources of variation could be reduced as much as biologically possible, 30 observations of 18 different animals would be preferable to 12 observations of 6 different animals. If a basal or test feed were about as variable in net energy content as the basal diet used here $(\mathrm{SEM}=0.184, \mathrm{SD}=1.005 \mathrm{MJ} / \mathrm{kg})$, then the smallest even number of animals used to estimate the $\mathrm{NE}_{\mathrm{L}}$ within $0.419 \mathrm{MJ} / \mathrm{kg}$ of the true mean would be 24 $\left[\left(\mathrm{n}=4 \mathrm{~S}^{2} / \mathrm{L}^{2}=4 \times 1.005^{2} / 0.419^{2}=23.01\right)\right.$ at $\mathrm{P}<0.05 ; \mathrm{S}=$ standard deviation; and $\mathrm{L}=$ the precision used to estimate mean [9]].

\subsection{Systematic Variation Caused by Technique}

The tendency for goats and cows that were fed greater amounts of the various feeds to contain more body fat as a fraction of total body weight may also have contributed to variations. Some workers argue that fat animals produce more heat per kilogram than lean animals [11] and others suggest that the reverse is true [12,13]. A larger and more active gut, caused by adaptation to and processing of the more generous feed allotment is postulated to be the mechanism for more HP in fat animals [11]. However, a given weight of adipose tissue produces less heat than the same weight of more metabolically active lean tissue. The fact that these are offsetting effects may explain why nutritionists have not yet established linear or nonlinear coefficients for body fat content that reduce variation in net energy estimates when fat is included with body weight in estimates of HP. One objective of future research in this area is to measure the effect of body composition on HP and to use this information to refine the $\mathrm{HP}$ component of $\mathrm{NE}_{\mathrm{L}}$ energy estimates based on $\mathrm{D}_{2} \mathrm{O}$ dilution for dairy feeds by including body composition elements in the HP prediction equations.

\section{CONCLUSIONS}

Analysis of $\mathrm{D}_{2} \mathrm{O}$ dilution permits repeated, safe, rapid, and noninvasive estimates of body composition in lac- 
tating ruminants $[1,2]$. This technique has been applied to feeding trials that permit estimates of feed $\mathrm{NE}_{\mathrm{L}}$ from the sum of milk energy, changes in body energy, and HP.

To ensure more accurate and precise $\mathrm{NE}_{\mathrm{L}}$ estimates by this technique in the future, we recommend that 1) feeding periods should last $8 \mathrm{wk}$; 2) at least 24 observations should be taken per $\mathrm{NE}_{\mathrm{L}}$ estimate; 3 ) the fraction of the test feed in the total diet should be maximized without creating intake problems, non-energy nutrient deficiencies or excesses; 4) scales or balances should be accurate to within less than $1 \%$ of the total feed or animal weight; 5) variation in both basal diet and test feeds should be minimized by mixing, blending, and testing in advance and by running as many observations simultaneously as feasible to avoid seasonal variation in forage source; 6) variation in feed intake estimates should be minimized by designing feeding stations that quantitatively recover orts; and 7) variation in voluntary activity should be minimized by providing for some defined exercise while confining animals sufficiently to prevent running and jumping.

\section{ACKNOWLEDGEMENTS}

Data compilation and laboratory analyses were carried out and coordinated at the Department of Animal Science, University of California, Davis by Scott Taylor and Treasure Shell. Norm Hinman and Bill Neel also helped conduct some laboratory analyses. Most of the animal care and data collection were provided by La Donna Foley, Charles Gachuiri, Dean Scott, Mark Hanigan, Adrienne Horowitz, Adrienne Fong, Milo Bravo, Brou Kouakou, Rebecca Harwood, John Kincheloe, Walter Paroczai, and Charles Rowe. Donald Bath provided his experience with dairy cattle feed formulation, guidance and critical review of the manuscript. This research was supported by California Milk Producers Advisory Board Grant \#881772, USDA Hatch Grant CA-D*ASC4445-H, and USDA Regional Research Grant CA-D*-ASC-5240-RR.

\section{REFERENCES}

[1] Brown, D.L., De Peters, E.J., Taylor, S.J. and Baldwin, R.L. (1989) The influence of sometribove, USAN (recombinant methionyl bovine somatotropin) on the body composition of lactating cattle. Journal of Nutrition, $\mathbf{1 1 9}$ 633.

[2] Brown, D.L. and Taylor, S.J. (1986) Deuterium oxide dilution kinetics to predict body composition in dairy goats. Journal of Dairy Science, 69, 1151. doi:10.3168/jds.S0022-0302(86)80515-X

[3] Byers, F.M. (1979) Extraction and measurement of deuterium oxide at tracer levels in biological fluids. Analytical Biochemistry, 98, 208. doi:10.1016/0003-2697(79)90728-0

[4] Thonney, M.L., Touchberry, R.W., Goodrich, R.D. and Meiske, J.C. (1976) Intraspecies relationship between fasting heat production and body weight: A reevaluation of $\mathrm{W}^{75}$. Journal of Animal Science, 43, 692-704.

[5] Flatt, W.P. and Coppock, C.E. (1963) The fasting metabolism of dry, non-pregnant adult dairy cows. Journal of Dairy Science, 46, 638.

[6] Brody, S. (1945) Bioenergetics and growth. Reinhold Publ. Co., New York.

[7] Association of Official Analytical Chemists (1984) Official methods of analysis. 14th Edition, AOAC, Washington, DC.

[8] Goering, H.K. and Van Soest, P.J. (1975) Forage fiber analyses. (Apparatus, Reagents, Procedures and Some Applications) Agriculture Handbook No. 379. ARSUSDA, Washington, DC.

[9] Snedecor, G.W. and Cochran, W.G. (1980) Statistical methods. Iowa State College Press, Ames.

[10] National Research Council (1989) Nutrient requirements of dairy cattle. 6th Edition, National Academy of Sciences, Washington, DC.

[11] Ferrell, C.L. and Jenkins, T.G. (1984) A note on energy requirements for maintenance of lean and fat Angus, Hereford and Simmental cows. Animal Production, 39, 305. doi:10.1017/S0003356100041957

[12] Russel, A.J.F. and Wright, I.A. (1983) Factors affecting maintenance requirements of beef cows. Animal Production, 37, 329. doi: $10.1017 / \mathrm{S} 0003356100001938$

[13] Tess, M.W., Dickerson, G.E. Nienaber, J.A. and Ferrell, C.L. (1984) The effects of body composition on fasting heat production in pigs. Journal of Animal Science, 58, 99. 